\title{
Scientific Cooperation between the United States and Central and Eastern Europe and the Newly Independent States
}

\author{
DeAndra Beck \\ U.S. Department of Agriculture, Foreign Agriculture Service, Room 3222, South Building, \\ Washington, DC 20250-4300 \\ Bharat P. Singh \\ Agricultural Research Station, Fort Valley State College, Fort Valley, GA 31030-3298
}

Over the past 50 years, the scientific structure of the satellite countries of Central and Eastern Europe (CEE) and the Newly Independent States (NIS) followed the communist pattern of centralized control (Glenday, 1993). Policy decisions and research priorities were made at the top with little input from scientists or stakeholders. Because of the economic importance of the agriculture sector, agricultural research was often subject to a greater degree of centralized planning than theoretical fields of basic science.

Agricultural research in CEE and the NIS was conducted within three main structures: the academies of science; research institutes affiliated with the ministries of agriculture; and, to a lesser degree, within agricultural universities. Academies of science were honorary organizations comprised of eminent scholars. The academies wielded influence and power within the scientific community because they managed large budgets. Much of the theoretically based agricultural research came under the purview of academy scientists. The agricultural research institutes were designed to serve the needs of large state farms and cooperatives through the improvement of production agriculture. The research focus of these institutes was in applied areas such as plant and animal breeding, engineering and machinery design, aquaculture, and forestry. With some exceptions, the role of the agricultural universities was vocational education. Students attending universities were not adequately trained in research methods and seldom participated in active research programs. Interaction between universities, research institutes, and academies was minimal. Duplication of research was common, and multi-disciplinary projects were rare.

Though the current structure of agricultural science in CEE and the NIS continues to reflect that of the past, there have been some changes in recent years (Dragavtsev and Alexanian, 1993; Glenday, 1993; Jeffrey, 1994). First and foremost, funding for agricultural science at research institutes has been reduced dramatically. In the past, large communities - often up to 500 people-worked in field stations and agricultural research institutes. All of these people were paid by the

\footnotetext{
Received for publication 22 May 1995. Accepted for publication 22 Aug. 1995. We gratefully acknowledge the assistance of Timothy Fratta and Rebecca Weber, U.S. Dept. of Agriculture summer interns, in compiling the list of research funding opportunities.
}

state. When the state systems were dismantled, hundreds of people at these research facilities and field stations lost their jobs. Most institutes immediately downsized by half and have since been forced to make further reductions. Though some lost jobs were superfluous or redundant, the collapse of these communities has affected the scale of scientific endeavor and the morale of the scientists who remained.

To generate revenues, many research institutes have become quite creative. It is now common to find institutes contracting out services for soil testing, seed production, plant breeding, vaccine development, artificial insemination, water analysis, etc. Some of these contracts are held with local farmers, while others are held with government ministries and the emerging private sector. International companies frequently contract with research facilities to support market development or related research and development.

Entrepreneurial scientists from the region are exploring every avenue to keep their research interests alive. For this purpose, they are looking to the agricultural research community in Europe and the United States for collaboration. This need provides a rare opportunity for the U.S. researchers to tap the energies of a well-trained pool of scientists for common benefit.

\section{BENEFITS OF AND BARRIERS TO COLLABORATION}

Benefits. The organizational and funding uncertainties within the agricultural research communities of CEE and the NIS offer increased opportunities for international collaboration. The eastward focus of the past has now shifted westward. Open borders have facilitated international travel in both directions. Germplasm collections are now accessible for study and exchange, and curators are eagerly searching for assistance in maintaining the collections. Moreover, U.S. and international donors have possessed the foresight to provide technical assistance funding at a crucial time to preserve and catalog germplasm collections in CEE and the NIS (Dalrymple, 1994; Dragavtsev and Alexanian, 1993; Strauss, 1994a).

In the horticultural sciences, years of active research and access to unique and indigenous germplasm from the region brings a wealth of knowledge to the field. Local researchers have published data on apricot (Prunus armeniaca L.) cultivars from Armenia (Arzoumanian et al., 1986), the North
Caucases (Dragavtseva, 1986), and Moldova (Isakova, 1986); plum (Prunus spp.) cultivars from Georgia (Bajashvili, 1990); blueberry (Vaccinium spp.) and cranberry (Vaccinium macrocarpon Ait) cultivars from Lithuania (Butkus and Butkiene, 1985) and other Eastern European countries (Pliszka, 1993); and walnut (Juglans spp.) cultivars from Ukraine (Andrienko et al., 1990) and Moldova (Tsurkan and Melnichenko, 1990). Other researchers have published data on cherry (Prunus avium L.) production in Eastern Europe (BulatovicDanilovich, 1993) and on tomatoes (Lycopersicon esculentum Mill.) for industrial processing (Andryushchenko and Shilina, 1990). With funding from the U.S. Dept. of Agriculture, Cornell Univ. scientists travelled to Kazakhstan and Kyrgyzstan to collect apple (Malus domestica Borkh.) germplasm (Adams, 1994). A list of the national coordinators for the European cooperative program for conservation and exchange of crop genetic resources is available for further reference (Strauss, 1994b).

Two major factors prevalent in CEE and NIS countries make collaboration in the region very attractive for U.S. scientists and institutions. First, the scientists from CEE and the NIS are well-trained. Though a lack of access to current literature and technologies has impeded scientific development in some fields, CEE and NIS scientists have received a strong theoretical education. Second, collaboration with CEE and NIS countries is very cost-effective. Salaries of scientists are very low, ranging from $\$ 50$ to $\$ 300$ per month. Even if an incentive salary is added to this base salary, the cost of supporting scientists for research collaboration remains quite low. Therefore, it is possible to fund the research efforts of an entire laboratory for 1 year on the equivalent yearly salary of a research assistant or postdoctoral associate in the United States.

Barriers. There are, however, challenges to overcome when initiating joint research efforts. In any international collaboration, communication plays a pivotal role in establishing an effective relationship. In CEE and the NIS, communication is made difficult by several factors, in addition to the obvious language and cultural differences. Economic hardships and past fears of uncontrolled communication have hindered the development of telecommunication infrastructure in the region, creating a barrier to efficient uses of phone, fax, and Internet services. Computers and fax machines are usually shared by entire research departments, if they exist at all. Yet, improved telecommunication is a high priority for the new 
governments of CEE and the NIS, and acquisition and installation of new technologies are proceeding rapidly. Many scientists in the region are gaining access to the Internet, particularly in urban centers.

One of the most subtle, yet frustrating, barriers to cooperation is corruption. Low salaries, high consumer prices, and the total collapse of law enforcement and judicial oversight has culminated in varying degrees of corruption throughout the region. Scientists may be affected by corruption either directly or indirectly: scientific equipment is stolen or sold for profit, bribery and protection money is demanded, funds are siphoned off for personal use. We hope that these problems are temporary, resulting from the challenges of transforming a centrally planned economy to a decentralized, privatized economy.

Wagner (1993) has outlined the pros and cons of undertaking international technologybased joint ventures. Although the article focuses primarily on commercial joint ventures, the steps outlined for planning and evaluating the prospects for a successful joint venture are readily applied to planning for international research collaboration. Included in her discussion are a six-phase strategic approach and criteria for decision-making that are relevant to international research and development. Scientists who have an interest in international collaboration would be well-served to review this article for planning purposes.

\section{SOURCES OF FUNDING FOR COLLABORATION}

The U.S. government has developed a strategy for assistance to CEE and the NIS based on four major components: democracy, privatization, health, and environment (U.S. Dept. of State, 1994). The assistance effort has been designed to achieve visible results in a short period. It was widely believed that CEE countries would need U.S. assistance for 3 to 5 years to complete the transition from communism to capitalism. While the early assumptions held true for countries such as the Czech Republic, Slovenia, and Estonia, it has become apparent that the CEE assistance effort will continue in most countries in the region well into the 21st century. Funding for NIS assistance efforts remains quite political, although multiyear programming is currently under way. There is no doubt that countries such as Russia, Ukraine, and Belarus have different assistance requirements than Moldova, Georgia, and the Central Asian Republics.

The primary agency responsible for strategic development and technical assistance funding to the CEE and NIS is the U.S. Agency for International Development (AID). Congress authorized funding for technical assistance to the CEE and NIS under the SEED Act and the FREEDOM Support Act, respectively. Congress appropriates funds on a yearly basis to AID under this authorizing legislation. AID has the responsibility to disburse funds to public, private, and nonprofit organizations to implement technical projects in the region. Interagency assistance efforts in CEE and the NIS are coordinated by the Office of the Coordinator in the U.S. Dept. of State.

The assistance strategy developed by AID and the Office of the Coordinator does not support using SEED Act and FREEDOM Support Act funding for collaborative research between U.S. scientists and scientists from CEE and the NIS. Some funds have been allocated to agricultural research institutions in CEE and the NIS, but they are earmarked solely for policy reform and restructuring. The general rationale for excluding the research community from technical assistance funds is based on the short-term nature of the assistance effort. Research funding is perceived by AID and the State Dept. to be a long-term rather than short-term investment. Moreover, scientific research was well-funded in the past, and some believe that present research needs can be adequately met by restructuring and reallocating existing human and financial resources.

Table 1 provides a list of potential funding sources for agriculturally related scientific cooperation between U.S. scientists and scientists from CEE and the NIS. The list has been drawn from various sources, including informational letters, pamphlets, and brochures distributed by various funding organizations.

The list in Table 1 is exemplary, not comprehensive, and includes U.S. Government programs and sources from private foundations and technical societies. The U.S. Government-funded programs existed before SEED and FREEDOM Support Act funding, albeit at comparatively lower funding levels. Most notably, the U.S. State Dept.'s Joint Fund programs in CEE are absent from this list. As of fiscal year 1996, it is likely that funds for these programs will cease due to U.S. budget reductions.

Thus, it can be concluded that collaboration between U.S. scientists and scientists from CEE and the NIS provides mutual benefits that extend beyond the accomplishment of shared

Table 1. Funding sources for scientific cooperation between the United States and Central and Eastern Europe and the Newly Independent States.

\begin{tabular}{|c|c|c|c|c|c|}
\hline $\begin{array}{l}\text { Name and address } \\
\text { of donor agency }\end{array}$ & Grant area & $\begin{array}{c}\text { Amount/ } \\
\text { grant }\end{array}$ & Duration & $\begin{array}{c}\text { No. awards } \\
\text { (per year) }\end{array}$ & Deadline \\
\hline $\begin{array}{l}\text { American Orchid Society } \\
\text { 6000 South Olive Ave. } \\
\text { West Palm Beach, FL 33405-4159 } \\
\text { Tel: } 407.585 .8666 \\
\text { Fax: } 407.585 .0654\end{array}$ & Orchid research & $\$ 500-\$ 12,000$ & $\leq 3$ years & Not specified & 1 Jan. and 1 Aug. \\
\hline $\begin{array}{l}\text { Conservation, Food, and Health } \\
\text { Foundation } \\
\text { c/o Grant Management Assoc. } \\
\text { 230 Congress St., 3rd Floor } \\
\text { Boston, MA 02110 } \\
\text { Tel: } 617.426 .7172 \\
\text { Fax: } 617.426 .5441\end{array}$ & $\begin{array}{l}\text { Projects on conservation, ecology, } \\
\text { environment, wildlife, agriculture, } \\
\text { health, health services }\end{array}$ & $\begin{array}{l}\$ 10,000- \\
\$ 25,000\end{array}$ & Not applicable & $25-30$ & 1 Jan. and 1 Aug. \\
\hline $\begin{array}{l}\text { Council for International Exchange } \\
\text { of Scholars } \\
\text { Fulbright Scholar Program Director } \\
\text { Recruitment and Liaison } \\
\text { 3007 Tilden St., NW, Suite 5M } \\
\text { Washington, DC 20008 } \\
\text { Tel: } 202.686 .4000 \\
\text { Fax: } 202.362 .3442\end{array}$ & $\begin{array}{l}\text { Basic and applied field research in the } \\
\text { sciences and humanities, university } \\
\text { teaching, advanced research, } \\
\text { graduate study, and teaching in } \\
\text { elementary and secondary schools }\end{array}$ & $\begin{array}{l}\text { Stipend, } \\
\text { travel, } \\
\text { miscellaneous } \\
\text { allowances }\end{array}$ & $2-12$ months & $\begin{array}{l}\text { More than } 1,000 \\
\text { teaching and } \\
\text { research } \\
\text { awards in } \\
\text { about } 135 \\
\text { countries }\end{array}$ & $\begin{array}{l}15 \text { June-1 Aug., } \\
\text { varies with } \\
\text { country }\end{array}$ \\
\hline $\begin{array}{l}\text { CRPB Program } \\
\text { Proposal Services Branch } \\
\text { CSREES } \\
\text { U.S. Dept. of Agriculture } \\
\text { AG Box } 2241\end{array}$ & $\begin{array}{l}\text { 1. Multi-institutional Research Group } \\
\text { Awards } \\
\text { Research in all areas of plant } \\
\text { biology; DOE/NSF/USDA } \\
\text { joint program }\end{array}$ & $\begin{array}{l}\text { About } \\
\$ 60,000 / \text { year }\end{array}$ & $\leq 5$ years & Not specified & Not specified \\
\hline $\begin{array}{l}\text { Washington, DC } 20250 \\
\text { Tel: } 202.401 .4871 \\
\text { Fax: } 202.401 .6488\end{array}$ & $\begin{array}{l}\text { 2. Interdisciplinary Research } \\
\text { Training Group Awards } \\
\text { Interdisciplinary research in } \\
\text { plant biology; DOE/NSF/USDA } \\
\text { joint program }\end{array}$ & $\begin{array}{l}\text { About } \\
\$ 300,000 / \text { year }\end{array}$ & $\leq 5$ years & Not specified & Not specified \\
\hline
\end{tabular}


Table 1. Continued.

\begin{tabular}{|c|c|c|c|c|c|}
\hline $\begin{array}{l}\text { Name and address } \\
\text { of donor agency }\end{array}$ & Grant area & $\begin{array}{c}\text { Amount/ } \\
\text { grant }\end{array}$ & Duration & $\begin{array}{c}\text { No. awards } \\
\text { (per year) }\end{array}$ & Deadline \\
\hline $\begin{array}{l}\text { Fertilizer Research and } \\
\text { Education Program } \\
\text { Contracts Office, Room } 155 \\
\text { California Dept. of Food } \\
\text { and Agriculture } \\
\text { 1220 N St. } \\
\text { Sacramento, CA } 94271-0001 \\
\text { Tel: } 916.653 .5340 \\
\text { Fax: } 916.653 .2407\end{array}$ & $\begin{array}{l}\text { Research, demonstration, and educa- } \\
\text { tion of environmentally safe and } \\
\text { agronomically sound use and } \\
\text { handling of fertilizer materials }\end{array}$ & $\begin{array}{r}\text { Maximum } \\
\$ 30,000\end{array}$ & $\begin{array}{l}\text { Multi-year } \\
\text { projects } \\
\text { accepted, } \\
\text { funding only } \\
\text { guaranteed } \\
\text { for 1 year }\end{array}$ & Not specified & April \\
\hline $\begin{array}{l}\text { Food and Agriculture Organization } \\
\text { of the United Nations } \\
\text { Liaison Office for North America } \\
1001 \text { 22nd St., NW } \\
\text { Washington, DC } 20437\end{array}$ & $\begin{array}{l}\text { 1. Fellowships and scholarships } \\
\text { Agriculture, fisheries, forestry, } \\
\text { nutrition, agricultural economics } \\
\text { and statistics, rural institutions } \\
\text { and services, and related areas }\end{array}$ & $\begin{array}{l}\text { Stipend, } \\
\text { training fees, } \\
\text { travel, books, } \\
\text { tuition }\end{array}$ & $\begin{array}{l}2 \text { months- } \\
2 \text { years }\end{array}$ & Not specified & Not specified \\
\hline $\begin{array}{l}\text { Tel: } 202.653 .2453 \\
\text { Fax: } 202.653 .5760\end{array}$ & $\begin{array}{l}\text { 2. Group Training Activities } \\
\text { Animal production and health, } \\
\text { atomic energy, economic analysis, } \\
\text { fisheries, forestry and forest } \\
\text { products, land and water develop- } \\
\text { ment, nutrition, plant production } \\
\text { and protection, public information, } \\
\text { rural institutions and services, and } \\
\text { statistics }\end{array}$ & $\begin{array}{l}\text { Cost of } \\
\text { the course }\end{array}$ & $\begin{array}{l}2 \text { weeks- } \\
6 \text { months }\end{array}$ & Not specified & Not specified \\
\hline & $\begin{array}{l}\text { 3. Andre Meyer FAO Research } \\
\text { Fellowships } \\
\text { Agriculture, fisheries, forestry, } \\
\text { nutrition, agricultural economics, } \\
\text { and statistics }\end{array}$ & $\begin{array}{l}\text { Stipend, } \\
\text { training fees, } \\
\text { travel }\end{array}$ & 24 months & $\begin{array}{l}\text { four, offered } \\
\text { biannually }\end{array}$ & Not specified \\
\hline $\begin{array}{l}\text { Horticultural Research Inst. } \\
\text { Suite 500, 1250 I St., NW } \\
\text { Washington, DC } 20005 \\
\text { Tel: } 202.789 .2900 \\
\text { Fax: } 202.789 .1893\end{array}$ & $\begin{array}{l}\text { Production, marketing, and landscape } \\
\text { applications of woody landscape } \\
\text { plants }\end{array}$ & $\begin{array}{r}\text { Maximum } \\
\$ 15,000\end{array}$ & $\begin{array}{l}1 \text { year, } \\
\text { renewable }\end{array}$ & Not specified & 1 May \\
\hline $\begin{array}{l}\text { Institute of International Education } \\
\text { Hubert H. Humphrey Fellowship } \\
\text { Program } \\
\text { 1400 K St., NW } \\
\text { Washington, DC } 20005 \\
\text { Tel: 202.326.7701 } \\
\text { Fax: 202.326.770 } \\
\text { e-mail: hhh@iie.org }\end{array}$ & $\begin{array}{l}\text { For mid-career professionals from } \\
\text { developing countries, Eastern } \\
\text { and Central Europe, and the } \\
\text { former Soviet Union to pursue } \\
\text { a year of study and related } \\
\text { practical professional experience } \\
\text { in the United States in fields } \\
\text { of natural resources and } \\
\text { environmental management, } \\
\text { agricultural development/economics, } \\
\text { health and nutrition, and public } \\
\text { administration }\end{array}$ & $\begin{array}{l}\text { Travel, tuition, } \\
\text { stipend, books, } \\
\text { professional } \\
\text { activities }\end{array}$ & $\begin{array}{l}1 \text { academic } \\
\text { year }\end{array}$ & $150-200$ & $\begin{array}{l}\text { Variable by } \\
\text { country; final } \\
\text { deadline } 15 \text { Nov. }\end{array}$ \\
\hline \multirow[t]{2}{*}{$\begin{array}{l}\text { International Research and } \\
\text { Exchanges Board (IREX) } \\
\text { 1616 H St., NW } \\
\text { Washington, DC } 20006 \\
\text { Tel: } 202.628 .8188 \\
\text { Fax: } 202.628 .8189\end{array}$} & $\begin{array}{l}\text { 1. Individual advanced research } \\
\text { opportunities for U.S. faculties } \\
\text { and doctoral candidates } \\
\text { Individual and collaborative research } \\
\text { and intellectual exchanges in } \\
\text { Central and Eastern Europe, } \\
\text { the former Soviet Union, and the } \\
\text { People's Republic of Mongolia in } \\
\text { unrestricted fields }\end{array}$ & $\begin{array}{l}\text { Travel, stipend, } \\
\text { research } \\
\text { allowance, } \\
\text { support for } \\
\text { accompanying } \\
\text { family may be } \\
\text { available }\end{array}$ & $2-12$ months & $\begin{array}{l}\text { Grants } \\
\text { awarded in } \\
\text { 1993-94: } \\
\text { CEE, 57; } \\
\text { Eurasia, 48; } \\
\text { Mongolia, } 3\end{array}$ & $\begin{array}{l}\text { November for } \\
\text { following } \\
\text { September }\end{array}$ \\
\hline & $\begin{array}{l}\text { 2. U.S. host universities for graduate } \\
\text { students from Eurasia and the Baltics } \\
\text { (Edmund S. Muskie and Freedom } \\
\text { Support Act Fellows) } \\
\text { 1- to 2-year degree and nondegree } \\
\text { programs in professional fields }\end{array}$ & $\begin{array}{l}\text { Travel, book, } \\
\text { partial tuition, } \\
\text { living expenses } \\
\text { health insurance }\end{array}$ & $1-2$ years & About 150 & $\begin{array}{l}\text { January for } \\
\text { following fall }\end{array}$ \\
\hline $\begin{array}{l}\text { Life Sciences Research Foundation } \\
\text { Postdoctoral Fellowship Program } \\
\text { c/o Lewis Thomas Laboratories } \\
\text { Washington Rd. } \\
\text { Princeton Univ. } \\
\text { Princeton, NJ 08544 } \\
\text { Tel: } 609.258 .3551\end{array}$ & $\begin{array}{l}\text { Training and support for young } \\
\text { scientists in life sciences }\end{array}$ & $\begin{array}{l}\$ 35,000 / \text { year } \\
\text { covers stipend, } \\
\text { travel, research } \\
\text { expenses }\end{array}$ & 3 years & $15-20$ & 1 Oct. \\
\hline $\begin{array}{l}\text { National Research Council } \\
\text { Office for Central Europe } \\
\text { and Eurasia } \\
\text { 2101 Constitution Ave., NW } \\
\text { Washington, DC } 20418 \\
\text { Tel: } 202.334 .2644\end{array}$ & $\begin{array}{l}\text { 1. Twinning Program } \\
\text { Funds basic research between } \\
\text { U.S. and CEE scientists } \\
\text { (no production agriculture research) } \\
\text { in Belarus, Bulgaria, Kazakhstan, } \\
\text { Moldova, Romania, and Ukraine }\end{array}$ & $\begin{array}{l}\$ 12,000- \\
\$ 15,000 \\
\text { Covers travel, } \\
\text { scientific sup- } \\
\text { plies, miscel- } \\
\text { laneous costs }\end{array}$ & 2 years & Not specified & 1 Sept. \\
\hline
\end{tabular}




\begin{tabular}{|c|c|c|c|c|c|}
\hline $\begin{array}{l}\text { Name and address } \\
\text { of donor agency }\end{array}$ & Grant area & $\begin{array}{c}\text { Amount/ } \\
\text { grant }\end{array}$ & Duration & $\begin{array}{c}\text { No. awards } \\
\text { (per year) }\end{array}$ & Deadline \\
\hline Fax: 202.334.2614 & $\begin{array}{l}\text { 2. COBASE Travel/Host Grants } \\
\text { Funds short-term and longer-term } \\
\text { collaborative basic research } \\
\text { (no production agriculture research) } \\
\text { between U.S. scientists and } \\
\text { scientists in CEE and the NIS }\end{array}$ & $\begin{array}{l}\$ 2,200-\$ 2,500 \\
\text { short term; } \\
\$ 3,000- \\
\$ 15,300 \\
\text { long term }\end{array}$ & $\leq 6$ months & Not specified & $\begin{array}{l}29 \text { Dec., } 8 \text { Apr., } \\
8 \text { July, } 5 \text { Aug. }\end{array}$ \\
\hline $\begin{array}{l}\text { National Research Council } \\
\text { 2101 Constitution Ave., NW } \\
\text { Washington, DC } 20418 \\
\text { Tel: } 202.334 .2760 \\
\text { Fax: } 202.334 .2759\end{array}$ & $\begin{array}{l}\text { Resident Research Associateship } \\
\text { Programs GR430 } \\
\text { All areas of theoretical and applied } \\
\text { fundamental sciences, including } \\
\text { health sciences, clinical research, } \\
\text { environmental sciences, plant } \\
\text { physiology, and biotechnology }\end{array}$ & $\begin{array}{l}\$ 29,000- \\
\$ 35,000 \text { for } \\
\text { research } \\
\text { associates, } \\
\text { higher stipend } \\
\text { for senior } \\
\text { associates, } \\
\text { relocation } \\
\text { reimbursment, } \\
\text { professional } \\
\text { travel }\end{array}$ & 12 months & 300 & $\begin{array}{l}15 \text { Jan., } 15 \text { Apr., } \\
\text { and } 15 \text { Aug. }\end{array}$ \\
\hline $\begin{array}{l}\text { Scientific Cooperation Program } \\
\text { USDA/FAS/ICD/RSED } \\
\text { Room 3230 South Building } \\
\text { Washington, DC 20250 } \\
\text { Tel: 202.720.3282 } \\
\text { Fax: 202.690.1955 } \\
\text { e-mail: hneil@ag.gov }\end{array}$ & $\begin{array}{l}\text { International agricultural research } \\
\text { of high priority to the United States, } \\
\text { particularly biological control, } \\
\text { forestry, exotic diseases and pests, } \\
\text { germplasm, human nutrition, } \\
\text { new uses, trade barriers, and } \\
\text { natural resources management }\end{array}$ & $\begin{array}{l}\$ 5,000-\$ 30,000 \\
\text { travel, stipend, } \\
\text { insurance, } \\
\text { equipment, } \\
\text { publication }\end{array}$ & $\begin{array}{l}4 \text { weeks- } \\
3 \text { years }\end{array}$ & $\begin{array}{l}\text { About } 50 \\
\text { (short term and } \\
\text { long term) }\end{array}$ & $\begin{array}{l}\text { September of the } \\
\text { preceding fis- } \\
\text { cal year }\end{array}$ \\
\hline $\begin{array}{l}\text { Stanley Smith Horticultural Trust } \\
\text { P.O. Box } 365 \\
\text { Cambridge CB2 1HR, U.K. } \\
\text { Tel: } 44.223 .336299 \mathrm{AM} \\
\quad 44.223 .60100 \mathrm{PM} \\
\text { Fax: } 44.223 .336278\end{array}$ & $\begin{array}{l}\text { Amenity horticulture and } \\
\text { horticulture education }\end{array}$ & Varies & $\begin{array}{l}\text { Depends on } \\
\text { the nature } \\
\text { of the pro- } \\
\text { ject }\end{array}$ & Varies & 15 Mar., 15 Sept. \\
\hline $\begin{array}{l}\text { The Charles A. Lindbergh } \\
\text { and Anne Morrow Foundation } \\
\text { Lindbergh Grants Program } \\
708 \text { South 3rd St., Suite } 110 \\
\text { Minneapolis, MN 55415 } \\
\text { Tel: } 612.338 .1703 \\
\text { Fax: } 612.338 .6826\end{array}$ & $\begin{array}{l}\text { Agriculture, aviation/aerospace, } \\
\text { arts and humanities, biomedical } \\
\text { research, conservation of natural } \\
\text { resources, exploration, health and } \\
\text { population sciences, intercultural } \\
\text { communication, oceanography, } \\
\text { waste disposal management, water } \\
\text { resource management, and wildlife } \\
\text { preservation }\end{array}$ & $\leq \$ 10,580$ & Not specified & 10 & $\begin{array}{l}\text { Second Tuesday } \\
\text { in June }\end{array}$ \\
\hline $\begin{array}{l}\text { The Eurasia Foundation } \\
\text { Program Office } \\
\text { 1527 New Hampshire Ave., NW } \\
\text { Washington, DC } 20036 \\
\text { Tel: } 202.234 .7370 \\
\text { Fax: } 202.234 .7377\end{array}$ & $\begin{array}{l}\text { Educational programs, expert advice, } \\
\text { training, and policy research to } \\
\text { support economics and democratic } \\
\text { reform in the Newly Independent } \\
\text { States (NIS) }\end{array}$ & $\begin{array}{l}\text { Total } \$ 16 \\
\text { million/year } \\
\text { Average U.S. } \\
\text { grant: } \$ 60,000 ; \\
\text { Average NIS } \\
\text { grant: } \$ 25,000\end{array}$ & Not specified & $\begin{array}{l}\text { According to the } \\
\text { annual budget }\end{array}$ & Not specified \\
\hline $\begin{array}{l}\text { The Ford Foundation } \\
\text { 320 East 43rd St. } \\
\text { New York, NY } 10017 \\
\text { Tel: } 212.573 .5000 \\
\text { Fax: } 212.599 .4584\end{array}$ & $\begin{array}{l}\text { Rural development, environment, } \\
\text { agriculture }\end{array}$ & Variable & Not applicable & Not specified & None \\
\hline $\begin{array}{l}\text { The International Society of } \\
\text { Arboriculture-Research Trust } \\
\text { Dept. of Botany and Microbiology } \\
\text { Ohio Wesleyan Univ. } \\
\text { Delaware, OH } 43015 \\
\text { Tel: } 614.368 .3508 \\
\text { Fax: } 217.355 .9516\end{array}$ & Research on shade and landscape trees & $\$ 2,500$ & Not applicable & 10 & 1 Nov., 15 Apr. \\
\hline \multirow[t]{2}{*}{$\begin{array}{l}\text { The Kosciuszko Foundation } \\
\text { 15 East } 65 \text { th St. } \\
\text { New York, NY } 10021 \\
\text { Tel: } 212.734 .2130 \\
\text { Fax: } 212.623 .4552\end{array}$} & $\begin{array}{l}\text { 1. Graduate and Postgraduate } \\
\text { Study in Poland } \\
\text { For Americans to continue } \\
\text { their graduate and postgraduate } \\
\text { studies in Poland }\end{array}$ & Tuition, stipend & Not specified & Not specified & 15 Jan. \\
\hline & $\begin{array}{l}\text { 2. Exchange Program with Poland } \\
\text { For Poles to further their research } \\
\text { studies at accredited institutions } \\
\text { of higher learning in the } \\
\text { United States }\end{array}$ & $\begin{array}{l}\text { Travel, stipend, } \\
\text { books, } \\
\text { insurance }\end{array}$ & 1 year & Not specified & 15 Oct. \\
\hline $\begin{array}{l}\text { Wallace Genetic Foundation } \\
4900 \text { Massachusetts Ave., NW } \\
\text { Suite } 220 \\
\text { Washington, DC } 20016 \\
\text { Tel: } 202.966 .2932 \\
\text { Fax: } 202.362 .1514\end{array}$ & $\begin{array}{l}\text { Agriculture, conservation, environ- } \\
\text { ment, higher education, nutrition }\end{array}$ & $\$ 150,000$ & Not applicable & Not specified & Not specified \\
\hline
\end{tabular}


research objectives. International collaboration has far-reaching benefits such as access to biological material, scientific resources, and technologies unavailable in the United States (Herdt, 1986; Ruttan, 1986). Despite the challenges affiliated with international cooperation, there is a great potential in developing collaborative research programs. With high levels of interest from CEE and NIS scientists and catalytic funding available through numerous organizations and agencies, it is quite feasible to pursue cooperative research efforts with scientists in the region.

\section{Literature Cited}

Adams, S. 1994. Returning to the apple's birthplace. Agr. Res. 42(11):18-21.

Andrienkio, M.V., F.T. Zatokovoy, and L.F. Satina 1990. Walnut in the Ukraine. Acta Hort. 284:339341.

Andryushchenko, V.K. and M.V. Shilina. 1990. State and prospects of breeding and genetic methods for tomato varieties designated for industrial processing. Acta Hort. 277:259-261.

Arzoumanian, P.R., V.M. Michaelian, and M.E. Amirian. 1986. Apricot cultivation zones in Armenia. Acta Hort. 192:19-22.

Bajashvili, E.I. 1990. Studies of some species of Prunus Mill. genus. Acta Hort. 283:31-34.

Bulatovic-Danilovich, M. 1993. Observations on cherry production and research in Eastern Europe. Annu. Rpt. Secr. State Hort. Soc. Mich. 123:65-68.

Butkus, V. and Z. Butkiene. 1985. Some results in highbush blueberry and cranberry research in the Lithuanian SSR. Acta Hort. 165:93-96.

Dalrymple, W. 1994. Russian and U.S. sign landmark environmental agreement to aid Vavilov and Komarov botanical institutes. Diversity 10(2):13-14.
Dragavtsev, V.A. and S.M. Alexanian. 1993. Dramatic changes in former Soviet Union require new approaches at VIR. Diversity 9(1/2):14 15.

Dragavtseva, I.A. 1986. Ways of apricot culture development in the North Caucasus. Acta Hort. 192:23-28.

Glenday, C. 1993. An overview of science and technology reform in Central and Eastern Europe, 1990-1993. Natl. Sci. Foundation. NSF/ Europe Rpt. 67.

Herdt, R.W. and J.R. Anderson. 1986. The contribution of the CGIAR centers to world agricultural research, p. 39-64. In: V.W. Ruttan and C.E. Pray (eds.). Policy for agricultural research. Westview Press, Boulder, Colo.

Isakova, M.D. 1986. Some results of apricot selection in Moldavia. Acta Hort. 192:323-327.

Jeffrey, C. 1994. Systematic botany in the states successor to the Soviet Union. 43(2):233-239.

Pliszka, K. 1993. The blueberry industry and research in eastern Europe: Review. Acta Hort. 346:41-43.

Ruttan, V.W. 1986. Toward a global agricultural research system, p. 65-97. In: V.W. Ruttan and C.E. Pray (eds.). Policy for agricultural research. Westview Press, Boulder, Colo.

Strauss, D.G. (ed.). 1994a. Donors rally to rescue Eastern Europe's threatened genetic resources. Diversity 9(4):8-12.

Strauss, D.G. (ed.). 1994b. National coordinators for the European cooperative program for conservation and exchange of crop genetic resources. Diversity 10(4):38-39.

Tsurkan, I.P. and L.A. Melnichenko. 1990. Short review of English walnut variety investigation in Moldavia. Acta Hort. 284:187-189.

U.S. Department of State. 1994. SEED Act implementation strategy. Washington, D.C.

Wagner, C.K. 1993. Strategy first in international joint ventures. J. Technol. Transf. 18(1/2):39-48.

\section{INSERT ENVIRONMENTAL GROWTH CHAMBERS AD (negative enclosed)}

DROP KEYLINE, but retain vertical rule at left 